\title{
Feminist International Relations: Some Research Agendas for a World in Transition
}

Elisabeth Prügl

Graduate Institute, Geneva

J. Ann Tickner

American University

This is an Accepted Manuscript of an article published by Bristol University Press in European Journal of Politics and Gender 1,1 (2018). Available online at https://doi.org/10.1332/251510818X15272520831193 


\section{Feminist International Relations: Some Research Agendas for a World in Transition}

Global political and economic conditions and the struggles around them have animated knowledge production in feminist International Relations (IR) since its beginnings in the late 1980s. In the early twenty-first century, these conditions

include a weakened international liberal order in which principles ranging from free trade to collective security and democracy are under attack; a "war on terror", declared by the U.S. after the attacks of September 11, 2001, that has led to massive political violence, from terrorism to the wars in Afghanistan and the Middle East; and a sharpening of global inequalities in the aftermath of the 2008 financial crisis. The triumphalism of the end of the Cold War has given way to recognition of US decline, the proneness of capitalism to sudden crises, and the inability of current policy tools to address urgent problems of inequality. Feminist movements are mobilizing to advance gender justice and shape new futures. Contemporary feminist IR speaks to these issues, interpreting meanings, offering critique, and probing alternatives.

We begin by tracing the emergence of feminist IR in the late 1980s and 1990s. We then identify some key questions and ongoing debates that have emerged since the turn of the century as feminist voices from the Global South have joined what has become a vibrant and expanding body of knowledge. In the main part of our review, we focus on just two sub-fields within feminist IRsecurity studies and global political economy, careful not to replicate the divide between the study of violence and security on the one hand and political 
economy on the other that has been rightly criticized by certain feminists. ${ }^{1}$ Importantly, this article is not attempting to define "a field". It omits significant bodies of feminist scholarship not easily subsumed under the categories of political economic and security that focuses for example on human rights, global media, development and foreign policy. And we understand that we speak from our specific locations as feminist scholars —-working in the U.S and Europe on security, global political economy, and governance. We conclude by suggesting some current, and possible future, research agendas.

\section{Feminist International Relations}

Feminist approaches to IR entered the field in the late 1980s and early 1990s, around the same time as the end of the Cold War. The first generation of feminist IR scholars devoted themselves to critiquing the theoretical and methodological underpinnings of the field. This scholarship made visible the gendered characteristics of key concepts, such as the sovereign state-conceived in the image of modern man as instrumentally rational and autonomous; the anarchic state of nature-populated by disembodied and sex-less individuals not in need of nurture; power narrowly understood as domination; and a definition of security that ignored structural violence and environmental threats (Tickner 1992; Sylvester 1994). Feminist scholars sought to make women visible in international politics, argued for the relevance of gender as an analytical lens, for feminism as a standpoint, and for post-positivist methodologies (Enloe 1993; Peterson and Runyan 1993; Zalewski 1993).

${ }^{1}$ See conversations in Politics \& Gender June 2015 and December 2017. 
Whereas the first generation of IR feminists were mostly from the Global North, since 2000, the field has grown and diversified to the point that it is impossible to speak of one IR feminism. Black, Global South, indigenous and queer feminists have introduced new issues and new perspectives to the field. They call attention to intersectionality—the impossibility of generalizing about women whose lives are very different depending on race class and geographical location (Basu 2016; Agathangelou 2016; Ling 2013; Crenshaw 1989; Mohanty 2003; Stewart Harawira 2005; Weber 2015). And feminists have been paying more attention to men and masculinity (Zalewski and Parpart 2008). Theoretical approaches used to understand these various issues include positivist, critical, constructivist, post-/de-colonial and queer approaches (Ackerly and True 2010; Ackerly, Stern, and True 2006). While different issues and ways to understand them mean that there are now many feminisms, for most IR feminists there remains a basic understanding of what makes knowledge feminist, Feminists ask feminist questions; they build knowledge from the lives of women; they are reflexive about their knowledge building; and they believe in working with activists to better the lives of women and to empower them (Tickner 2005).

In the next two sections, we outline some research directions in two subfields of feminist IR - feminist security studies and global political economy. In each section, we first discuss scholarship that explores empirical relationships between gender and security or economic practices. We then turn to literature that probes the way in which these practices have been taken up in institutions of international governance and to what effect. 


\section{Feminist Security Studies}

The 2001 terrorist attacks in the US and the militarized response, as well as the continuation of ethno-nationalist wars, many of them in the Global South, have provided the background for the emergence of feminist security studies as a distinctive sub-field within feminist IR. ${ }^{2}$ Although it remains a contested concept, feminists have redefined the meaning of security. They generally see insecurity as multi-dimensional, including not only harm from physical violence, but also harm from structural violence that occurs when individuals are denied the means to live an adequate life. And indigenous scholars remind us that security also means living in harmony with the natural world (Stewart Harawira 2005; Altmann 2013). Most IR feminists have delinked security from its association with national security, suggesting that the security of individuals is often in tension with the security of the state (Moon 1997). Feminists have not only drawn our attention to rape as a weapon of war but also to sexual and genderbased violence more generally. Given the multiplicity of security issues, multiple research agendas have opened up. We will focus first on literature that explores the relationship between gender and violence; we then discuss research on the effects of feminist activism and gender mainstreaming on security governance.

\section{Gender and Violence}

The relationship between gender and violence has animated feminist IR from its beginnings. How can we understand the gendered division of labor or the seeming male monopoly on the conduct of war and the prevalence of women in

\footnotetext{
2 We realize that defining feminist security studies as a field is contested. For an elaboration of this debate see Politics and Gender (2010) and International Studies Perspectives (2013).
} 
peace movements (Goldstein 2003)? Is there a causal relationship between gender and violence?

Much of post-positivist feminist research finds this relationship, which assumes an essential gender difference mapped onto a separation of war and peace, problematic. But there is now a debate on this topic, largely as a result of quantitative scholarship that has established a correlation between the degree of gender inequality in a country and the tendency for the country to solve conflicts violently (Caprioli 2000, 2005; Melander 2005). Scholars have explained this correlation by resorting to intrinsic attitudes and behaviors of women and men, drawing on evidence from public opinion research, biology and psychology (V. M. Hudson et al. 2009; Caprioli and Boyer 2001). Using positivist methodologies, they have largely ignored the core feminist insight that gender differences are socially constructed and productive of unequal relations of power between women and men. Instead, much of this work asks questions about the likely behavior of states, based on degrees of inequality between women and men. Against essentialist arguments that see inequality between women and men as causing violence and war, and equality as productive of peace, postpositivist feminists have more often treated war and gender as co-constituted. Gender does not cause war, but it inhabits war. Gender is a pervasive force, a power relation that defines identities, informs symbolic orders and directs material processes (Cockburn 2010; Cohn 2012, 3-5; Sjoberg 2013, 2009). Gender relations are imbricated in processes of militarization, and war reproduces binary gender constructions, militarist masculinities, and corresponding femininities (Crane-Seeber 2016; Joachim and Schneiker 2012). Researchers employing these types of arguments tend to generalize, not by 
establishing laws, but by identifying social mechanisms that give force to gendered processes. Two examples of such mechanisms are first, the "logic of masculinist protection" (Young 2003), which calls on men to defend women and the homeland, making it possible to think of war as an honorable activity in which to engage; and second, the militarization of masculinities, typically associated with a denigration of women and everything considered feminine in order to encourage male war fighting. This disparagement of women is most virulently expressed in sexual violence. As men are being trained for war and societies are being militarized, violence against women becomes part of the fabric of everyday lives (Detraz 2012; Duncanson 2009; Whitworth 2007; Goldstein 2003).

Whether there is a relationship between sexual and gender-based violence and armed violence has emerged as a key site of investigation for feminist IR. Many feminists emphasize that such violence is not exceptional and not limited to wartime, that there is continuity between rape in wartime and peacetime (Davies and True 2015; MacKenzie 2012; Freedman 2011). Accordingly, they question explanations of conflict-related sexual violence as related to the organizational characteristics of militaries and militias (such as put forward by Cohen 2013 or Butler et al. 2007), because such explanations ignore that using sexual violence in these contexts is effective only because of unequal gender relations that transcend war.

For many women worldwide security is as much about being safe in the home as it is about violence related to conflict. The United Nations has estimated that 35 percent of women worldwide have experienced physical and/or sexual intimate partner violence at some point in their lives. Some national studies 
show up to 70 percent and it is estimated that only 40 percent of women seek help. ${ }^{3}$ Sexual and gender-based violence is particularly prevalent in indigenous communities. Using an intersectional analysis, Rauna Kuokkanen (2015: 282) claims that the combination of colonialism, racism, sexism and poverty makes indigenous women particularly vulnerable. Where poverty and other forms of oppression are widespread, issues such as gender-based violence tend to be seen as less pressing.

The suggestion that violence in war and peace may form a continuum ruptures the binary of war and peace, a binary that is deeply gendered because it essentializes the association of men with war and women with peace. It fails to imagine that men can be peaceful and women warlike, hides violence during "peace" and caring during "war," and perpetuates hierarchical orderings in which women and peace always appear as denigrated. Against this, a strand of research in feminist IR that seeks to disturb this binary has emerged. This research has documented the extensive participation of women in armed violence, war fighting and terrorism (Shekhawat 2015; Åhäll 2015; Sjoberg and Gentry 2009, 2007; Parashar 2009; Alison 2004). It has also critiqued the tendency for masculinity to be thought of as toxic, becoming an easy explanation for a range of problems, from war fighting to sexual violence, while ignoring the fluidity and situatedness of gender constructions (Zalewski 2017; Duncanson 2015). And, it has begun to question the identification of sexual violence as maleto-female, exploring constructions of masculinity driving such violence but also

3 UN Women (2018) Facts and figures: Ending violence against women. Available:. http://www.unwomen.org/en/what-we-do/ending-violence-against-women/facts-andfigures [16 March 2018]. 
beginning to shine a light on male victimization (Zalewski et al. 2018; Zalewski and Runyan 2015; Eriksson Baaz and Stern 2013).

Thus, the feminist literature on gender and violence ranges from studies that find the causes of war in gender inequality and patriarchy, to those that identify the co-constitution of gender and violence, and those that disrupt the association of gender with the binary of war and peace. We see different potentials in these bodies of literature. First, the exploration of gender as (constitutively) causing violence continues to be relevant. In particular, we believe that more micro-level, empirical research can add important new insights on gendered mechanism that drive violence and war, from patriarchal constructions of femininity and masculinity to economic inequality and exploitation (Meger 2016; Eriksson Baaz and Stern 2013; True 2012). Second, we see exciting potential in scholarship that seeks to disturb the multiple binaries that constitute security discourse and prop up sovereign authority: war and peace, men and women, aggressor and victim, knower and known (Millar and Tidy 2017; Weber 2016, 2015; Shepherd and Sjoberg 2012).

\section{Governing Security with Gender: From Norm Diffusion to "Governance Feminism"}

From the Cold War struggles against nuclear weapons in Europe and North America to movements to end violent conflicts in Ireland, Palestine, Liberia and Colombia, women's movements have been working for peace and women have been demanding seats at peace tables (Kaufman and Williams 2010; Cockburn 2007). Feminist peace politics have impacted the security practices of states through the UN's Women, Peace, and Security agenda, which has been put in place through the 2000 UN Security Council Resolution (UNSCR) 1325 and seven 
subsequent Security Council resolutions. While the agenda constitutes a significant feminist victory, some have criticized the way in which feminism has come to exercise power as movement ideas have entered security institutions in a way reminiscent of what Halley et al. (2006) have called "governance feminism". An extensive body of literature has investigated and critiqued the impacts of the agenda through its translations into local contexts and through its discursive effects.

First, because of 1325, UN peace-building operations have become opportunity structures for advancing feminist agendas; scholars have documented how local non-governmental organizations use 1325 for their campaigns (Jenichen 2013; Irvine 2013; Farr 2011). Contributing to a broader IR literature on norm diffusion and norm contestation, feminists have also identified translations that are less successful, sometimes implementing gender equality norms insufficiently or without sensitivity to gendered power relations, such as in reintegration practices that reproduce female combatants as victims in Sierra Leone (MacKenzie 2012, 2009) and sometimes adjusting international norms to local contexts in surprising ways, such as the implementation of UNSCR 1325 enabling women's groups in Israel to survive the hostile political reactions to the Second Intifada (Aharoni 2014; see also Basini 2013). This literature is particularly extensive with regard to National Action Plans, mandated by 1325 and designed to implement the women, peace, and security agenda, identifying tensions between rhetoric and practice, and highlighting the (in)compatibilities of international themes with local realities (Basini and Ryan 2016; George 2016; Lee-Koo 2016; Olsson and Gizelis 2015; Olonisakin, Barnes, and Ikpe 2010). 
In addition to looking at local impacts, feminists also have explored the discursive effects of the women, peace, and security agenda focusing on the way in which it has become a tool for government in the Foucaultian sense-how. it constitutes subjects, offers logics to justify intervention, and suggests the tools for such intervention. They have criticized the way international discourses frame women only as victims, especially of sexual violence (Puechguirbal 2010; Shepherd 2008; Otto 2006); when they recognize them as agents they often do so in an essentialized form, as mothers, nurturers and peace-builders (Shepherd 2017; N. F. Hudson 2009). Another concern is that feminist agendas have become embedded in a neoliberal order sustained by a discourse on war and the right to intervention (Jabri 2004; Harrington 2011; Väyrynen 2004), and into counterterrorism strategies where they reproduce historically gendered, racial, sexual and class hierarchies (Pratt 2013; Nesiah 2013; Pratt and Richter-Devroe 2011). However, some feminist scholars continue to see the emancipatory potential of the women, peace, and security agenda, considering it a "backdoor move" to insert new feminist visions into governance projects (H. Hudson 2012, 455; Duncanson 2016; Shepherd 2011; N. F. Hudson 2009, esp. p. 112).

The literature on the women, peace, and security agenda paints a decidedly complex picture with co-optations and disciplining accompanying the political work of activists who use the agenda to their advantage. Calling this "governance feminism" makes visible the fact that feminist change agendas are not free from power. But it is necessary to push beyond painting a picture where feminism appears as either coopted or a pure source of empowerment. As a force embedded in history, feminism generates a range of effects that hopefully can be liberating and emancipatory, but may also have a dark side. There is a need and 
an opportunity for future research to probe the promises and pitfalls that accompany different translations of the women, peace, and security agenda and the openings and closures they achieve in different contexts.

\section{Feminist Political Economy}

Much of contemporary feminist IR focuses on violent conflict and security. But this emphasis is recent, a response to the US-declared "war on terror" in the new millennium. The early work in feminist IR was concentrated in development studies and global political economy and, a number of recent crises have reinvigorated feminist research in these areas. These include, the 2008 financial crisis, a steep rise in food prices in the mid-2000s, an ongoing crisis of care as aging populations in the North draw care resources from the South, and an ecological crisis threatening the planet's ecosystem. Along with these crises, feminist ideas have appeared on the agendas of economic and political elites, including multinational corporations, the World Bank, the World Economic Forum, and large foundations, such as the Gates and Clinton foundations, gaining a level of visibility unprecedented in international policy circles.

Research in feminist global political economy has always crossed disciplinary boundaries, drawing on feminist literatures in heterodox economics, development studies, social anthropology and geography. This is true also of new research in feminist global political economy, which we group into two bodies of literature. The first examines gendered relations of production in the context of capitalism and its multiple crises. The second documents the effects of feminist interventions in economic governance. 


\section{Gendered Relations of Production}

The gender division of labor is a core characteristic of relations of production under capitalism, and making visible women's paid and unpaid labor has long been a central concern of feminist political economy. Building on a solid body of earlier writings on women in global factories, recent feminist global political economy literature explores transnational economic linkages more extensively. For example, it follows women on "the tomato trail", tracing production practices from fields to supermarkets and fast food restaurants (Barndt 2008). It also documents women's reproductive work as domestic workers and sex workers, including the transfer of value through transnational care chains (Smith 2016; Rai and Waylen 2013; Chin 2013). The value of women's unpaid labor became hyper-visible in the aftermath of the financial crises. As was true in the context of structural adjustment of the 1990s and the Asian financial crisis of 1997 women's care labor helped buffer the impacts of crisis (Elias 2016; Elson 2014); scholars identified an increase in unpaid labor while also diagnosing a reinforcement of the public/private divide and a sharpening of gender inequality (Lux and Wöhl 2015; Rai and Waylen 2013).

Analyses of crises have built on and revived the tradition of feminist scholarship that works from the bottom up (Bair 2010), focusing on "the mundane matters" (Enloe 2011; Elias and Roberts 2016). They have made the connection between sex scandals (e.g. involving Dominique Strauss Kahn, the head of the International Monetary Fund), the masculinist cultures of financial institutions, corresponding patriarchal and racist policies and practices, and the role they play in affirming existing power relations (Montoya 2016; Hozic 2016; Enloe 2013). They also continue to explore how gender, race, and class structure 
everyday relations on factory floors, in fields, call centers, and households (Gunawardana 2016; Redden 2016).

In addition to this empirical work, scholars have developed new theoretical tools and concepts to give salience to the production of care values. They have called out the neglect of social protection in neoliberal policies and diagnosed an ongoing "crisis of reproduction" under financialized neoliberal capitalism as a necessary corollary of other crises (Fraser 2016; Fraser and Bedford 2008). They have developed the concept of "depletion" to capture the consequences on individuals, households and communities, of neglecting social reproduction (Rai, Hoskyns, and Thomas 2014). And they have provided interesting re-theorizations of the household, historicizing its form, questioning its boundaries, and suggesting its internationalization as transnational households follow the establishment of transnational economic networks (Halley 2011; LeBaron 2010; Safri and Graham 2010).

While labor relations continue to be the central preoccupation of feminist political economy, some literature has gone beyond a labor approach bringing into view exploitation through indebtedness, land expropriation, and environmental destruction, and developing arguments about the violence of the latest phase of capitalist expansion vis-à-vis women and marginalized populations. LeBaron and Roberts (2010) argue that capitalist relations are sustained by violence, that they are "carceral" in the sense that people's life choices and possibilities are locked into unfree capitalist social relations, for example through imprisonment, debt, and exploitative domestic labor. Some scholars have revived the concept of "primitive accumulation" to capture labor exploitation, the violent "expulsions" of people from the labor force, land grabs, 
and the destruction of the environment through the unfettered extraction and use of natural resources (Agathangelou 2016; Sassen 2014). They bring a gender perspective to the violent effects of transnational finance, resource competition, and environmental destruction.

This scholarship offers exciting new concepts and points towards new research agendas. It provides fresh thinking about the fundamental importance of care labor and its central role in sustaining families, communities, and the planet. It also contributes tools to rethink the ways both exchange and sharing are organized in transnational networks, from value chains to families. It finally invites a broadening of feminist research agendas for a better understanding of the way intersectional inequalities relate to financial, ecological, and care crises, and of the violence that sustains contemporary capitalism. A bottom-up approach to studying these matters continues to be one of the strengths of feminist global political economy.

\section{Governing the Economy with Gender: The Neoliberalization of Feminism?}

Complementing the bottom-up approach is an extensive feminist literature that examines how the international economy is governed from the top-down. It has shown the pernicious effects in the 1980s of the shift in economic orthodoxy towards neoliberalism in the Bretton Woods institutions. ${ }^{4}$ Despite superficial commitments to gender mainstreaming, there has been little attention to gender issues in these institutions until recently (Caglar 2013, 2009). Starting in 2008, and paralleling the financial crisis, the World Bank made a decisive push to foreground gender issues with a new action plan announcing

4 i.e. the World Bank, International Monetary Fund and World Trade Organization (before 1985 General Agreement on Trade and Tariffs), which have their origins in the 1944 conference at Bretton Woods, New Hampshire. 
that gender equality is "smart economics." Producing new knowledge that fed into its 2012 World Development Report, kicking off a communications campaign to pull along private businesses and states, and strengthening its gender mainstreaming practices, the Bank's initiative contributed to gaining gender issues unprecedented visibility in international policy circles.

A substantial body of feminist literature has engaged critically with this "neoliberalization of feminism": the construction of orthodox economics as good for women and of investments in women as good for growth; the obscuring of structural causes of inequality behind an essentialist celebration of empowered women; and the loss of accountability to women and feminist movements in business-led corporate social responsibility initiatives and public-private partnerships (Prügl 2016; Griffin 2015; Calkin 2015; Roberts 2015; Prügl and True 2014). Nancy Fraser (2009) has observed a resonance between certain feminist and neoliberal agendas, and has gone so far as suggesting that feminism has become a handmaiden of capitalism. Several other authors also draw on the notion of "feminist governmentality" to argue that gender has become a pervasive tool for governing conduct in the neoliberal economy; for example, bringing women into financial institutions is flagged as a solution to counterbalance male recklessness, or female entrepreneurship is celebrated as a way out of poverty (Repo 2015; Griffin 2015; Kunz 2011; Wöhl 2008).

But there are also efforts to recover progressive feminist politics from what have become somewhat stifling critiques of cooptation by probing openings in neoliberalized spaces and by recalling the breadth of feminist movement politics (Prügl 2015; Eschle and Maiguashca 2014). Particularly interesting is the recent call for a research program on cooptation that draws on 
scholarship from different disciplines to provide depth to the concept and develop pertinent research questions (de Jong and Kimm 2017).

Accepting the historical embedding of feminist politics in neoliberal capitalism opens up broad new research agendas to explore encounters of feminism with capitalist power, from corporate social responsibility projects to UN discourses. It also invites us to identify contradictions and tensions, and spaces for subversion, in such discourses. Finally, and perhaps most importantly, it summons us to identify radical alternatives. These might include the activism around a binding treaty on business and human rights currently being discussed in the UN Human Rights Council, whose goal it will be to hold multinationals and other businesses accountable to human rights standards (Gregoratti 2016). It also might include the proliferating bottom-up economic activities geared towards sharing and responsible householding that have been labeled "social and solidarity economy "(Verschuur et al. 2015; Bergeron and Healy 2013).

\section{Conclusion}

At the contemporary historical juncture of political instability and power transition, using a gender lens can provide important new insights on conflict, violence, and political economy and help envision alternatives. We have identified what we consider some of the cutting-edge debates in feminist security studies and feminist global political economy, including debates that reconnect these two artificially separated areas of research. In both, feminist scholarship addresses lived realities, connecting gender relations to relations of violence on the one hand, and to economic processes on the other. Scholarship in 
both these areas also addresses the way in which these connections are governed, or the way in which governments, international organizations, and feminist movements intervene to constitute and regulate lived realities.

While this scholarship pursues diverse research agendas, we would like to highlight six that we find particularly urgent for addressing the challenges of our times. The first pertains to the (constitutive) causalities linking (armed) violence and gender. In addition to the positivist research that has emerged on this topic, we find it important to further develop empirical research based on intersectional feminist theorizing. Joining the call by Carol Cohn (2011) for more "field-based ethnographic work" we believe that much can be gained from finegrained empirical research that traces intersectionally-gendered and sexed mechanisms of conflict escalation and de-escalation employing a combination of concepts from feminist and post-colonial theorizing while keeping in mind the political economy dimension (Duncanson 2016; Rigual 2017). Such work could connect to the turn towards the micro-level in civil war research more broadly, a literature that has entirely failed to understand the productivity of gender in dynamics of violence (e.g. Cederman and Vogt 2017). This is particularly urgent given the current policy focus on combatting violent extremism through microlevel prevention efforts that recruit women as allies.

Second, and in parallel, work needs to continue on the way the sex/gender binary supports binaries of war and peace employing insights from feminist and queer theory to disturb these binaries. Like no other body of contemporary IR literature, feminist IR rattles the foundations of what Betty Reardon (1985) has called the "war system" by exposing its sexed and gendered logics. Trenchant interpretations of phenomena, such as sexual violence against men (Zalewski et 
al. 2018) or the way in which sex/gender constitutes combat (Millar and Tidy 2017), unveil the imbrication of sex, gender, and violence and open space to question commonsensical binaries. A deconstructive research program that draws into IR the resources of sexuality and gender studies remains an urgent ongoing political task for feminist IR.

Third, building on the long-standing feminist interest in labor, it is fruitful to examine evolving labor relations in the contemporary context of a globalized economy characterized by sharpening inequalities, sexist authoritarianism, and violent methods of disciplining migrant labor. How do gender, race, class, and geographical location intersect to regulate labor relations in transnational value chains? How is care labor integrated into such chains? While feminist global political economy connects to the work of feminist geographers and anthropologists, we believe that IR scholars can bring distinctive knowledge about policy and regulation that transcends state boundaries in a mode of multilevel governance, connecting local to global politics (Bedford 2013).

Fourth, it is urgent to move feminist research beyond the focus on labor to generate a better understanding of contemporary processes of expropriation that menace populations and threaten the destruction of our planet. How do gender, race, and class operate intersectionally in contemporary practices of violent expropriation - in the form of exploitative finance, land grabs, and ecological destruction? This research can build on, but needs to move beyond, the notion of primitive accumulation in Marxist feminist literature to put in focus the violence of a range of contemporary economic processes and practices.

Fifth, the fraught engagement of feminism with institutions of international government needs more attention from feminist scholars. How have feminist 
agendas been absorbed into international governance, and how can such agendas remain transformative? This question responds to the sharp critique of the cooptation of feminism by neoliberal elites and institutions governing the international economy and global security. We join the call for a more thorough research program on cooptation (de Jong and Kimm 2017), one that makes visible contradictions, tensions, and openings. We are inspired by Nancy Fraser's (2009) insight that feminism cannot step outside history; as much as second wave feminism and the UN women's decade were enabled by a relatively stable liberal Cold War order, contemporary feminism faces institutionalized neoliberalism and anti-terrorist exceptionalism. There may be both resources and traps in the engagement with states and international organizations in this historical context, and they need to be studied rather than pre-judged

Finally, we believe that feminist scholarship is uniquely positioned to identify alternatives emerging from various global movement struggles. How are social movements and citizens around the world creating alternatives to existing economic and security orders? We have mentioned the examples of grassroots economic practices of solidarity and the efforts to hold corporations accountable. How do these practices influence hegemonic orders? What parallel grassroots and other initiatives in the security sector offer viable alternatives to masculinist security practices? How do these practices connect to international processes, in particular in light of a revival of power politics?

Underlying these research agendas is the conviction that two factors are central to the continuing vibrancy of feminist IR. First is its critical stance based on the recognition that scholarship itself is part of a power discourse, which makes it necessary to continually question seemingly unproblematic concepts 
and frameworks. The second relates to the importance of continuing to ask feminist questions. We cannot have a complete understanding of war and violence without asking about their gendered foundations. Nor can we comprehend the inequalities and injustices associated with the neoliberal global economy without seeing its situatedness in historically gendered, classed and racial structures of inequality. With our necessarily incomplete attempt to highlight some research agendas we hope to have illustrated the vibrancy of feminist IR and its importance for understanding the contemporary world. 


\section{Works Cited}

Ackerly, B., Stern, M. and True, J. eds. (2006) Feminist methodologies for International Relations. Cambridge: Cambridge University Press.

Ackerly, B. and True, J. (2010) Doing feminist research in political and social science. Houndmills, Basingstoke, Hampshire: Palgrave Macmillan.

Agathangelou, AM. (2016) 'Global Raciality of Capitalism and "Primitive” Accumulation'. In A Hozic and J True (eds), Scandalous economics, New York: Oxford University Press, pp 205-230.

Åhäll, L. (2015) Sexing war/policing gender: Motherhood, myth and women's political violence. Milton Park, New York: Routledge.

Aharoni, SB. (2014) 'Internal variation in norm localization: Implementing Security Council Resolution 1325 in Israel'. Social Politics: International Studies in Gender, State \& Society 21 (1): 1-25.

Alison, M. (2004) 'Women as agents of political violence: Gendering security'. Security Dialogue 35 (4): 447-463.

Altmann, P. (2013) 'Good Life as a social movement proposal for natural resources use: The indigenous movement in Ecuador', Consilience: The Journal of Sustainable Development, 10 (1): 59-71.

Bair, J. (2010) 'On difference and capital: Gender and the globalization of production'. Signs: Journal of Women in Culture and Society 36 (1): 203226.

Barndt, D. (2008) Tangled routes: Women, work, and globalization on the tomato trail. Landham, MD: Rowman \& Littlefield.

Basini, H. (2013) 'Gender mainstreaming unraveled: The case of DDRR in Liberia'. International Interactions 39 (4): 535-557. 
Basini, H., and Ryan, C. (2016) 'National Action Plans as an obstacle to meaningful local wwnership of UNSCR 1325 in Liberia and Sierra Leone'. International Political Science Review 37 (3): 390-403.

Basu, Soumita. 2016. “The Global South writes 1325 (too).” International Political Science Review 37 (3): 362-74.

Bedford, K. (2013) ‘Gender, institutions, and multilevel governance.” In G Waylen, K Celis, J Kantola, and LS Weldon, eds. The Oxford Handbook of Gender and Politics, Oxford, U.K.: Oxford University Press: 627-53.

Bergeron, S., and Healy, S. (2013) 'Beyond the business case: A community economics approach to gender, development and the social economy'. Paper presented at Conference on Potential and Limits of Social and Solidarity Economy. Geneva: UNRISD.

Butler, CK., Gluch, T. and Mitchell, NJ. (2007) 'Security forces and sexual violence: A cross-national analysis of a principal agent argument'. Journal of Peace Research 44, no. 6 (1 November): 669-687.

Caglar, G. (2009) Engendering der Makroökonomie und Handelspolitik: Potenziale transnationaler Wissensnetzwerke. Wiesbaden: VS Verlag für Sozialwissenschaften.

___. (2013) 'Feminist strategies and social learning in international economic governance'. In G Caglar, E Prügl, and S Zwingel (eds) Feminist strategies in international governance, London and New York: Routledge, pp. 249266.

Calkin, S. (2015). 'Feminism, interrupted? Gender and development in the era of “smart economics"'. Progress in Development Studies 15 (4): 295-307.

Caprioli, M. (2000) 'Gendered conflict'. Journal of Peace Research 37 (1): 51-68. 
_- - (2005) 'Primed for violence: The role of gender inequality in predicting internal conflict'. International Studies Quarterly 49 (2): 161-178.

Caprioli, M., and Boyer, MA. (2001) 'Gender, violence and international crisis'. Journal of Conflict Resolution 45 (4): 503-518.

Cederman, LE, and Vogt, M. (2017) 'Dynamics and Logics of Civil War.' Journal of Conflict Resolution 61 (9): 1992-2016.

Chin, CBN. (2013) Cosmopolitan sex workers: Women and migration in a global city. Oxford and New York: Oxford University Press.

Cockburn, C. (2007) From where we stand. London: Zed Books.

__—. (2010) 'Gender relations as causal in militarization and war: A feminist standpoint'. International Feminist Journal of Politics 12 (2): 139-157.

Cohn, C. (2011) '”Feminist Security Studies": Toward a Reflexive Practice.' Politics \& Gender 7, 4 (December): 581-86.

_-_. (2012) Women and wars: Contested histories, uncertain futures. Wiley.

Cohen, DK. (2013) Explaining rape during civil war: Cross-national evidence (1980-2009)'. American Political Science Review 107, no. 03 (August): $461-477$

Crane-Seeber, JP. (2016) 'Sexy warriors: The politics and pleasures of submission to the state'. Critical Military Studies 2 (1-2): 41-55.

Crenshaw, Kimberly. 1989. "Demarginalizing the Intersection of Race and Sex." University of Chicago Legal Forum 1: 139-67.

Davies, SE., and True, J. (2015) 'Reframing conflict-related sexual and genderbased violence: Bringing gender analysis back in'. Security Dialogue 46.6 (December): 495-512. 
de Jong, S., and Kimm, S. (2017). 'The co-optation of feminisms: A research agenda'. International Feminist Journal of Politics 19 (2): 185-200.

Detraz, N. (2012) International security and gender. Cambridge: Polity Press. Duncanson, C. (2009) 'Forces for good? Narratives of military masculinity in peacekeeping operations'. International Feminist Journal of Politics 11 (1): 63-80.

___. (2015) 'Hegemonic masculinity and the possibility of change in gender relations'. Men and Masculinities 18 (2): 231-248.

_——. (2016) Gender and peacebuilding. Cambridge: Polity Press.

Elias, J. (2016) 'Whose crisis? Whose recovery? Lessons learned (and not) from the Asian crisis'. In A Hozic and J True (eds) Scandalous economics: Gender and the politics of financial crises, New York: Oxford University Press, pp. 109-125.

Elias, J., and Roberts, A. (2016) 'Feminist global political economies of the everyday: From bananas to bingo'. Globalizations 13 (6): 787-800.

Elson, D. (2014) 'Economic crises from the 1980s to the 2010s: A gender analysis'. In SM Rai and G Waylen (eds) New frontiers in feminist political economy, London, New York: Routledge, pp. 189-212.

Enloe, C. (1993) The morning after: Sexual politics at the end of the Cold War. Berkeley, CA: University of California Press.

——_. (2011) 'The mundane matters'. International Political Sociology 5 (4): $447-450$.

__—. (2013) Seriously! Investigating crashes and crises as if women mattered. Berkeley, CA: University of California Press. 
Eriksson Baaz, M., and Stern, M. (2013) Sexual violence as a weapon of war?: Perceptions, prescriptions,pProblems in the Congo and beyond. London: Zed Books.

Eschle, C., and Maiguashca, B. (2014) 'Reclaiming feminist futures: Co-opted and progressive politics in a neo-liberal age'. Political Studies 62 (3): 634-651.

Farr, V. (2011) ‘UNSCR 1325 and women’s peace activism in the occupied Palestinian Territory'. International Feminist Journal of Politics 13 (4): $539-556$

Fraser, N. (2009) 'Feminism, capitalism and the cunning of history'. New Left Review, no. 56 (April): 97-117.

___. (2016) 'Contradictions of capital and care'. New Left Review, no. 100 (August): 99-117.

Fraser, N., and Bedford, K. (2008) 'Social rights and gender justice in the neoliberal moment: A conversation about welfare and transnational politics'. Feminist Theory 9 (2): 225-245.

Freedman, J. (2011) 'Explaining sexual violence and gender inequalities in the DRC'. Peace Review 23 (2): 170-175.

George, N. (2016) 'Institutionalising women, peace and security in the Pacific Islands: Gendering the "architecture of entitlements"?' International Political Science Review 37 (3): 375-389.

Goldstein, JS. (2003). War and gender: How gender shapes the war system and vice versa. Cambridge: Cambridge University Press.

Gregoratti, C. (2016) 'Cracks in the corporatisation of feminism'. Globalizations $13(6): 922-926$. 
Griffin, P. (2015) ‘Crisis, austerity and gendered governance: A feminist perspective'. Feminist Review 109 (1): 49-72.

Gunawardana, SJ. (2016) “"To finish, we must finish”: Everyday practices of depletion in Sri Lankan export-processing zones'. Globalizations 13 (6): 861-875.

Halley, J. (2011) 'After gender: Tools for progressives in a shift from sexual domination to the economic family'. Pace Law Review 31 (3): 887-924.

Halley, J., Kotiswaran, P., Shamir, H. and Thomas, Ch. (2006) 'From the international to the local in feminist legal responses to rape, prostitution/sex work, and sex trafficking: Four studies in contemporary governance feminism'. Harvard Journal of Law \& Gender 29: 335-423.

Harrington, C. (2011) 'Resolution 1325 and post-Cold War feminist politics'. International Feminist Journal of Politics 13 (4): 557-575.

Hozic, A. (2016) 'We, neoliberals'. In A Hozic and J True, eds. Scandalous economics, New York: Oxford University Press, pp. 165-178.

Hudson, H. (2012) 'A double-edged sword of peace? Reflections on the tension between representation and protection in gendering liberal peacebuilding'. International Peacekeeping 19 (4): 443-460.

Hudson, NF. (2009) Gender, human security and the United Nations: Security language as a political framework for women. London: Routledge.

Hudson, VM., Caprioli, M.. Ballif-Spanvill, B., McDermott, R., and Emmett, CF. (2009) 'The heart of the matter: The security of women and the security of states'. International Security 33 (3): 7-45. 
Irvine, JA. (2013) ‘Leveraging change: Women’s organizations and the implementation of UNSCR 1325 in the Balkans'. International Feminist Journal of Politics 15 (1): 20-38.

Jabri, V. (2004) 'Feminist ethics and hegemonic global politics'. Alternatives: Global, Local, Political 29 (3): 265-284.

Jenichen, A. (2013) ‘How Do Women’s Rights Norms Travel? Peace-Building Operations as Opportunity Structures in Bosnia'. In G Caglar, E Prügl, and S Zwingel, Feminist strategies in international governance, London and New York: Routledge, pp. 198-213.

Joachim, J., and Schneiker, A. (2012) 'Of "true professionals" and "ethical hero warriors": A gender-discourse analysis of private military and security companies'. Security Dialogue 43 (6): 495-512.

Kaufman, JP., and Williams, KP. (2010) Women and war: Gender identity and activism in times of conflict. Sterling, VA: Kumarian Press.

Kunz, R. (2011) The political economy of global remittances: Gender, governmentality and neoliberalism. Milton Park and New York: Taylor \& Francis.

Kuokkanen, R. (2015) 'Gendered violence and politics in indigenous communities: The case of aboriginal people in Canada and the Sámi in Scandinavia”. International Feminist Journal of Politics 17 (2): 271-288.

Ling, LHM. (2013) The DAO of world politics: Towards a Post-Westphalian, Worldist International Relations. New York: Routledge Chapman \& Hall. LeBaron, G. (2010) 'The political economy of the household: Neoliberal restructuring, enclosures, and daily life'. Review of International Political Economy 17 (5): 889-912. 
LeBaron, G., and Roberts, A. (2010) 'Toward a feminist political economy of capitalism and carcerality'. Signs: Journal of Women in Culture and Society 36 (1): 19-44.

Lee-Koo, K. (2016) 'Engaging UNSCR 1325 through Australia’s National Action Plan'. International Political Science Review 37 (3): 336-349.

Lux, J., and Wöhl, S. (2015) 'Gender inequalities in the crisis of capitalism: Spain and France compared'. In M Ebenau, I Bruff, and C May (eds) New Directions in Comparative Capitalisms Research, London: Palgrave Macmillan.

MacKenzie, M. (2009) 'Securitization and desecuritization: Female soldiers and the reconstruction of women in post-conflict Sierra Leone'. Security Studies 18 (2): 241-261.

———. (2012) Female soldiers in Sierra Leone: Sex, security, and post-conflict development. New York: NYU Press.

Meger, S. (2016) Rape loot pillage: The political economy of sexual violence in armed conflict. Oxford and New York: Oxford University Press.

Melander, E. (2005) 'Gender Equality and Intrastate Armed Conflict'. International Studies Quarterly 49 (4): 695-714.

Millar, KM., and Tidy, J. (2017) 'Combat as a moving target: Masculinities, the heroic soldier myth, and normative martial violence'. Critical Military Studies 3, no. (2 (4 May): 142-160.

Mohanty, C.T. (2003) Feminism without borders: Decolonizing theory, practicing solidarity. Durham, N.C.: Duke University Press 
Montoya, C. (2016) 'Exploits and exploitation: A micro and macro analysis of the "DSK Affair"'. In A Hozic and J True, Scandalous economics, New York: Oxford University Press, pp. 145-164.

Moon, KHS. (1997) Sex among allies: Military prostitution in U.S.-Korean relations. New York: Columbia University Press.

Nesiah, V. (2013) 'Feminism as counter-terrorism: The seduction of power'. In ML. Satterthwaite and J. Huckerby (eds) Gender, national security and counter-terrorism: Human rights perspectives. London and New York: Routledge, pp. 127-151.

Olonisakin, F., Barnes, K., and Ikpe, E. (2010) Women, peace and security: Translating policy into practice. London and New York: Routledge.

Olsson, L., and Gizelis, TI, eds. (2015) Gender, peace and security: Implementing UN Security Council Resolution 1325. London, New York: Routledge.

Otto, Dianne. (2006) 'Sign of weakness: Disrupting gender certainties in the implementation of Security Council Resolution 1325'. Michigan Journal of Gender \& Law 13: 113-175.

Parashar, S. (2009) 'Feminist International Relations and women militants: Case studies from Sri Lanka and Kashmir'. Cambridge Review of International Affairs 22 (2): 235-256.

Peterson, VS., and Runyan, AS. (1993) Global gender issues. Boulder, CO: Westview Press.

Pratt, N. (2013) 'Reconceptualizing gender, reinscribing racial-sexual boundaries in international security: The case of UN Security Council Resolution 1325 on “women, peace and security"'. International Studies Quarterly 57 (4): $772-783$. 
Pratt, N., and Richter-Devroe, S. (2011) ‘Critically examining UNSCR 1325 on women, peace and security'. International Feminist Journal of Politics 13 (4): 489-503.

Prügl, E. (2015) 'Neoliberalising feminism'. New Political Economy 20 (4): 614631.

__— (2016) 'Neoliberalism with a feminist face: Crafting a new hegemony at the World Bank'. Feminist Economics 23 (1): 30-53.

Prügl, E., and True, J. (2014) ‘Equality means business? Governing gender through transnational public-private partnerships'. Review of International Political Economy 21 (6): 1137-1169.

Puechguirbal, N. (2010) 'Discourses on gender, patriarchy and Resolution 1325: A textual analysis of UN documents'. International Peacekeeping 17 (2): $172-187$.

Rai, SM., Hoskyns, C. and Thomas, D. (2014) 'Depletion: The cost of social reproduction'. International Feminist Journal of Politics 16 (1): 86-105.

Rai, SM., and Waylen, G. (2013) New frontiers in feminist political economy. London and New York: Routledge.

Reardon, B. (1985) Sexism and the war system. New York: Teachers College Press,.

Redden, SM. (2016) 'What's on the line?: Exploring the significance of gendered everyday resistance within the transnational call center workplace'. Globalizations 13 (6): 846-60.

Rigual, C. (2017) 'Gendered Mechanisms of Conflict Management: Insights from Indonesia and Nigeria.' Paper presented at International Conference on Research for Development. September 6. Berne, Switzerland. 
Repo, J. (2015) The biopolitics of gender. Oxford, New York: Oxford University Press.

Roberts, A. (2015) 'The political economy of "transnational business feminism": Problematizing the corporate-led gender equality agenda'. International Feminist Journal of Politics 17 (2): 209-31.

Safri, M., and Graham, J. (2010) 'The global household: Toward a feminist postcapitalist international political economy'. Signs: Journal of Women in Culture and Society 36 (1): 99-125.

Sassen, S. (2014) Expulsions: Brutality and complexity in the global economy. Cambridge, MA: The Belknap Press of Harvard University Press.

Shekhawat, S., ed. (2015) Female combatants in conflict and peace. New York; Palgrave Macmillan.

Shepherd, LJ. (2008) Gender, violence and security: Discourse as practice. London: Zed Books.

_——. (2011) 'Sex, security and superhero(in)es: From 1325 to 1820 and beyond'. International Feminist Journal of Politics 13 (4): 504-521.

- - - (2017) Gender, UN peacebuilding, and the politics of space: Locating legitimacy. Oxford and New York: Oxford University Press.

Shepherd, LJ, and Sjoberg, L. (2012) 'Trans-bodies in/of war(s): Cisprivilege and contemporary security strategy'. Feminist Review, no. 101: 5-23.

Sjoberg, L. (2013) Gendering global conflict: Toward a feminist theory of war. Columbia University Press.

Sjoberg, L. (2009) 'Introduction to security studies: Feminist contributions'. Security Studies 18 (2): 183-213. 
Sjoberg, L., and Gentry, CE. (2007) Mothers, monsters, whores: Women's violence in global politics. London: Zed Books.

_—_, eds. (2009) Women, gender, and terrorism. Athens, GA: University of Georgia Press.

Smith, N. (2016) 'The global political economy of sex work'. In J. Steans and D. Tepe-Belfrage (eds) Handbook on Gender in World Politics, Cheltenham, UK; Northampton, MA: Edward Elgar Publishing, pp. 370-737.

Stewart-Harawira, M. (2005) The New Imperial Order: Indigenous Responses to Globalization. Karori, Wellington, Aotearoa-New Zealand: Huia Publishers.

Sylvester, Christine. (1994) Feminist theory and International Relations in a postmodern era. Cambridge University Press.

Tickner, JA. (1992) Gender in International Relations: Feminist perspectives on achieving global security. New York: Columbia University Press.

—_—. (2005) 'What is your research program? Some feminist answers to International Relations methodological questions'. International Studies Quarterly 49 (1): 1-22.

True, J. (2012) The political economy of violence against women. Oxford, New York: Oxford University Press.

Väyrynen, T. (2004) 'Gender and UN peace operations: The confines of modernity'. International Peacekeeping 11 (1): 125-142.

Verschuur, C., Guérin, I. and Hillenkamp, I., eds. (2015) Une économie solidaire peut-elle être féministe? Homo oeconomicus, mulier solidaria. Paris: L'Harmattan. 
Weber, C. (2015) 'Queer intellectual curiosity as International Relations method: Developing queer International Relations theoretical and methodological Frameworks'. International Studies Quarterly 60 (1): 11-23.

_-_. (2016) Queer International Relations: Sovereignty, sexuality and the will to knowledge. London, New York: Oxford University Press.

Whitworth, S. (2007) Men, militarism, and UN peacekeeping: A gendered analysis. Boulder, CO: Lynne Rienner Publishers.

Wöhl, S. (2008) ‘Global governance as neo-liberal governmentality: Gender mainstreaming in the European employment strategy'. In S Rai and G Waylen (eds) Global governance: Feminist perspectives, Houndmills, Basingstoke, Hampshire: Palgrave Macmillan, pp. 64-83.

Young, IM. (2003) 'The logic of masculinist protection: Reflections on the current security state'. Signs: Journal of Women in Culture and Society 29 (1): 125.

Zalewski, M. (1993) 'Feminist standpoint theory meets International Relations theory: A feminist version of David and Goliath?' Fletcher Forum of World Affairs 17: 13-32.

_-_. (2017) 'What's the problem with the concept of military masculinities?' Critical Military Studies 3 (2): 200-205.

Zalewski, M., Drumond, P., Prügl, E., and Stern, M. eds. (2018) Sexual violence against men in global politics. Houndmills, Basingstoke, Hampshire: Palgrave Macmillan.

Zalewski, M. and Parpart, J. eds. (2008) Rethinking the man question: Sex, gender and violence in International Relations. London: Zed Books. 
Zalewski, M., and Runyan, AS. (2015) “Unthinking” sexual violence in a neoliberal era of spectacular terror'. Critical Studies on Terrorism 8 (3): $439-455$. 